\title{
Open Access and Multilingual Approach to Communication Journals - The case and the editor's perspective of Observatorio (OBS*) Journal and the importance of Open Science for the Knowledge Society
}

\author{
Rita Espanha - ISCTE-IUL; ISLA-Lisboa, Portugal \\ rita.espanha@iscte.pt \\ Tiago Lima Quintanilha - OberCom, CIES-IUL, Lisboa, Portugal \\ Tiago.lima@obercom.pt
}

\begin{abstract}
This paper is about the contribution of the network society to a more open and cross-cultural way of making and publishing science. Basically, and speaking of Observatorio (OBS*) ejournal that has been published by OberCom-Lisbon, we believe that it might be relevant to note the tendency that science, in relation to its distribution model, has been showing lately. We think more traditional ways of publishing science in closed platforms (as paper format), where legitimacy was only dependent on the strict editorial team, has definitely lost its space in scientific publications on open online platforms, where legitimacy is now managed from the contribution of several experts: a model named Open Science. The open science movement replaces the traditional, hierarchical and centralized logic with more dynamic horizontal collaboration among peers: a form of community production, decentralized and self-selective. One can say that the growth of the OBS* e-journal in Portugal, rather than other scientific journals in the same areas, but in more traditional formats, clearly demonstrates that a self-centred science with fewer users and whose distribution of produced knowledge implies bigger reliance on funding, is giving rise to a more open science with more users, for whom the transmission of produced knowledge is more autonomous, effective, cheaper, etc.
\end{abstract}

Keywords: communication, open science, knowledge society, OBS* 


\section{In the Age of Information and Knowledge}

This topic must not be interpreted without prior contextual and historic analysis. Why? Because understanding these new ways of making and publishing science is, first of all, speaking of processes and mechanisms that enable such change. It is understanding what is happening or happened in terms of technological evolution, and its repercussions in the way of thinking and producing content, as well as the importance of what was agreed to be called Information Society in mediating this change. Well, information society is integrated in a change process, where new technologies are the main responsible. This societies organisation model is based on a social and economical development mode where information, as means of knowledge creation, has an important role in the production of wealth and contributes for citizens' wellbeing and quality of life. Advance of the information society is the chance for everybody to access information that is produced. As it is described in UNESCO reference boards, "Information Society is the corner stone of true knowledge societies". In fact, Information Society is the enhancer vehicle for knowledge transmission. And this vehicle, in the specific case of our study object, the OBS* e-journal, is materialised on a platform (online) that enhances scientific knowledge production, revision, diffusion and dissemination in the fields of communication and media, based on articles published there quarterly. Ultimately, and taking on the previous example, we could say that "knowledge management may be understood basically as a dynamic process supported by Information Technologies (IT) to create, receive, spread and (re)use knowledge (Probst et al, 2002: pp 35-37)." Bowker, in the same line of thought, refers that "informational infra-structures are central platforms towards Knowledge Economy (Bowker, 2001: p.8).” 


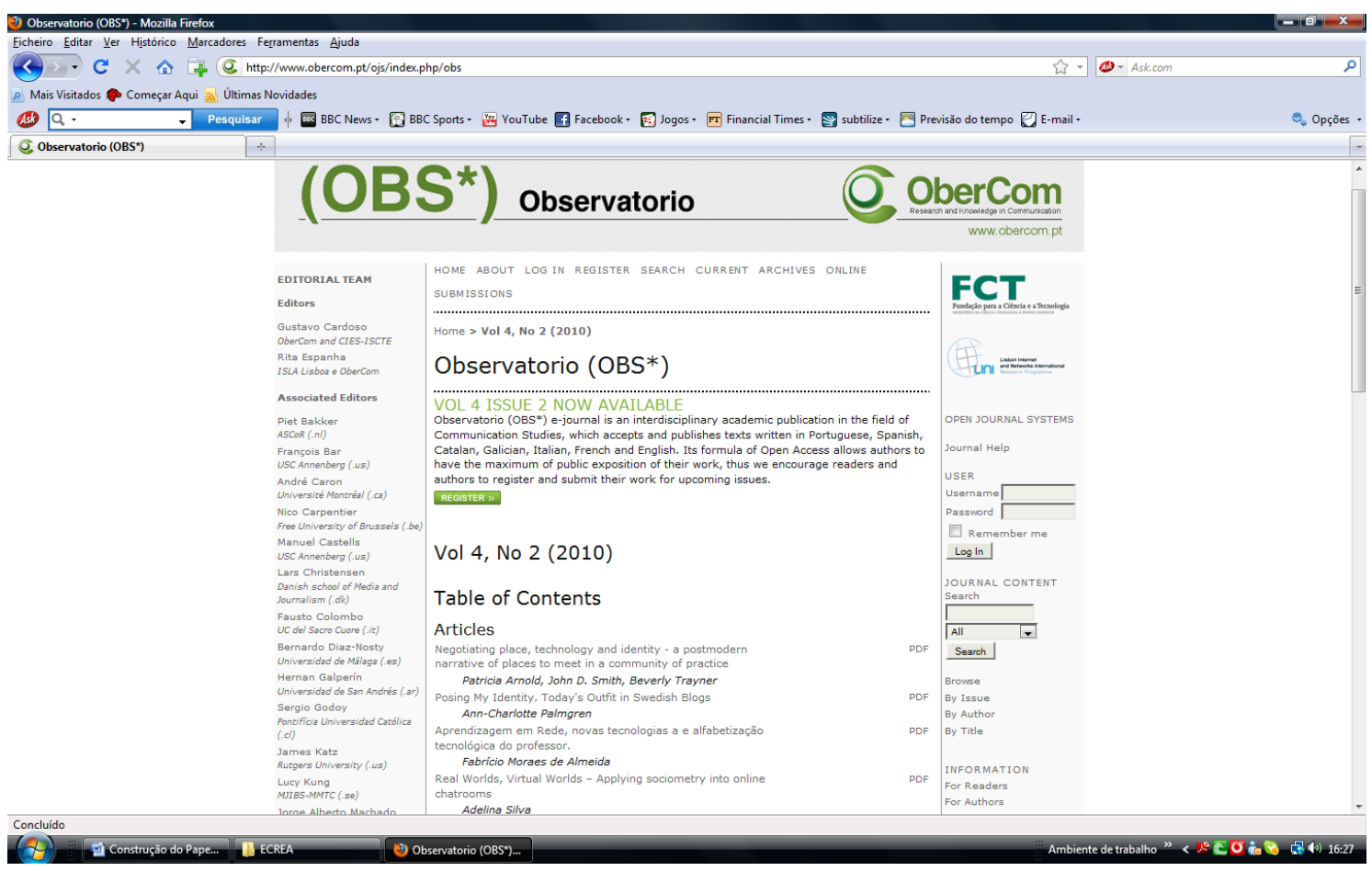

And here appears the relationship of Open Science with the questions raised in Information Society and its technological basis, in the sense the latter appears as the transition facilitator of a traditional science publication, self-centred and closed, to a more open science, of free reference. If we want to establish here a parallel with the jounal that is a case study for this article, Observatorio $\left(\mathrm{OBS}^{*}\right)$, we can state that this chain process: information technologies online publication platforms - knowledge dissemination, is not more than the reinvention of a previous structure of scientific production-diffusion, obsolete, which, as will shall demonstrate in 4 , presents results below the dissemination potentiality of scientific knowledge made possible by this new symbiosis between information society and open science.

In general, in order to have an idea of the range of this problematic, we could remind the concept of Lisbon Agenda, at a time Europe started to lose ground to the United States (beginning of the nineties) and at the end of the European catching-up to more developed countries (Japan and USA), it was clear that creating new competitive platforms was fundamental to sustain the European model. This idea prepared the transition towards knowledge-based economy and society, through the application of better policies within information society and its generalised access, Innovation and technological development. Therefore, "it became clear it was not possible to build a knowledge-based society without a 
more ambitious research and development policy, that could close in on the one practised by the American model. The reason was simple: only with a bet on R\&D it is possible to produce an essential source of knowledge creation, performing a crucial role in understanding the world we live in and also in improving the quality of life, social cohesion and governance models (Rodrigues et al, 2009: p.46).

The Lisbon Agenda was translated into new general orientations for the following policies: information society, research and development, innovation, enterprise, education, etc (Ibid).

In conclusion, we could say that events such as the ones leading to the creation of Observatorio (OBS*) (whose existence in Open Access appears as a formula enabling authors and their articles a maximum public exposure) are the ones allowing to sustain this transition from a more closed and inaccessible knowledge model, as the one we knew with the previous print run publication model, towards a knowledge society where information democratisation and reach have a magnitude never seen before.

\section{The New Paradigm of Science Construction and its Contribution to the Knowledge Society.}

What is science? How does Open Science appear?

It is important to situate our study object from the theoretical point of view, conceptually understanding the path science has taken, from the production-distribution point of view. First of all, what is science in fact?

The most consensual idea is, that science is made of a set of systematic research and investigation practices, with the purpose of creating knowledge about reality. Where does the open science concept come in, in partnership or community, crucial for the development of this text's problematic?

Daston (in Becker, 2001: p.5) mentions that, during the search for knowledge about reality, the conquest of scientific objectivity is made in a communitarian way, an universe of collaborations stimulated by improvements in the means of transportation and communication, creating "increasingly vast and densely connected viewer networks". Thus, the very essence of science is changing (Jankowski, 2007: http://jcmc.indiana.edu/vol12/issue2/jankowski.html). These changes result mainly from the 
use of electronic networks, enabling contact between researchers, (hence the connection with information technologies) and computing units with great processing and storage capacity, allowing working on great data volumes in a short time. This means that, nowadays, computer components and ICT are integrated in most production and distribution processes of scientific knowledge, allowing the reinvention of distribution means for produced content.

A significant part of the most common scientific work is electronic based: text elaboration, communication between scientists, etc., are examples of tasks where new technologies are commonly used. This way, we fulfil certain technical limitations, which previously prevented a given progress for Science. Using Internet and ICT in scientific work is now originating transformations in the ways of performing Science. The possibilities of communication and data transmission between researchers originated new forms of perception concerning the possibilities of Science and its mission also. The problematic of open science springs as fruit of this new communicational context.

New tools made available to scientists, mainly through Internet platforms, bring changes to the scientific production model, allowing, among other things, greater levels of collaboration, internationalisation, transparency and impact of scientific work.

This way, the form of a new scientific model that appears as an innovation booster is subject to interest from scholars, institutions and government entities (OCDE, 2004: http://www.oecd.org/document/0,2340,en_2649_34487_25998799_1_1_1_1,00.html).

We consider that this new model, Open Science, is structured mainly in three levels: research tools sharing; data sharing and access sharing under the form of publications.

Still, the concept, at least in general terms, is not entirely consensual from the grammar point of view, with a series of denominations created throughout the last years, which are not more than a kind of etymological upgrade of an increasingly relevant event. Thus, we can remind the term used by Nentwich (2003: p.22), Cyber-Science, which served to translate "all academic and scientific research activity, in the virtual space created by the computer network and advanced information and communication technologies in general". 
Atkins (2003: p.9) presented another idea, speaking of a cyberinfrastructure, which was related to Knowledge Economy as modern infrastructures, much as what was discussed previously about facilitator intermediaries of a more widespread dissemination process.

On other hand, in 1999, there was speeches about e-science, the large-scale science that would increasingly be based on global collaborations, distributed and made possible thanks to the Internet (centre staff draft Office of Science and Technology, UK).

Concerning the term e-research, it is more consensual in the academic milieu linked to social sciences and humanities, integrating Internet potentialities, hypertext, virtual visualisation and cybernetic communities (Jankowski 2007: article 10, p. 554).

Given this, we come to the concept of scientific openness with greater reach, which is called Open Science, reflecting the offer of several products of the research product, from the observation and data gathering phase to its final structure, as publications. Open Science is characterised also as a complementary alternative to copyright strategy concerning information production and distribution, assuming that data and information privatisation tends to delay scientific advances, as well as economical and social progress. This ownership status leads to artificial scarcity situations, which could be eliminated through functionalities developed in the digital world and, in particular, in the Internet.

According to Paul A. David (2003:http://ideas.repec.org/p/wpa/wuwpdc/0502006.html), Open Science is like the alternative scientific model to the copyright model of allocating resources for information production and distribution, which depends on a non-mercantile incentive system. According the author, access costs enforced by those who have copyrights over technical and scientific knowledge have terrible consequences for exploratory research programs, considered vital for Knowledge Economy, as we suggested previously.

But the dynamic of scientific progress also makes knowledge openness advantageous: only this way it is possible to validate discoveries and reduce unnecessary duplication of research efforts. The definition of Open Science, according to J. Daniel Gezelter (http://www.openscience.org/blog/?author=2) from OOPSE (Object-Oriented Parallel Simulation Engine), is linked to transparency on experimental methodology, public 
availability, and the possibility to reuse scientific data; public availability and scientific communication transparency and Web tools use to enable scientific collaboration.

Competitiveness and secrecy that oriented scientific work in the past, no longer seem to fit in the new visions of science for a growing number of researchers. In fact, Internet is becoming a support for scientists to make available laboratorial notes and first discoveries, increasing the scientific rhythm and being part of a broader debate dimension. These new practices do not fit the traditional academic culture, where typically scientists work alone, without disclosing results until its publication and without deepening all the details of the research process. This allows them to disclose their results and laboratorial notes to others, in any part of the globe. It also allows broadening debate inside and outside academia, integrating contributions and increasing the possibility of interdisciplinarity. As Cardoso (et al: 2009) states, it is a decentralisation process that strengthens knowledge reuse and dissemination at the same time it increases its recreation.

The Open Science movement, like Open source, substitutes traditional hierarchical logics, centralised by modular strategies, for horizontal dynamics of peer collaboration. Yochai Benkler called this "peer-production” (Benkler, 2002: p.8).
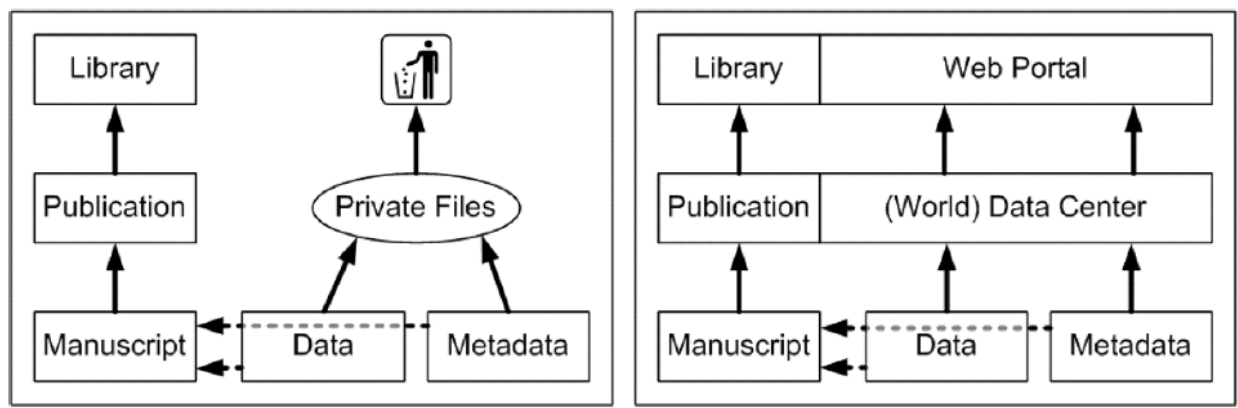

Source: (Klump et al, 2006:p.2)

This is a figure demonstrative of what happens, the dashed lines symbolising limited publication of data in conventional scientific journals. The remaining journals/publications are online and benefiting from a greater diversity of arrival points, as demonstrated by the uninterrupted lines. 
More than a debate about publication systems, The Open Access is created as a social movement born in the scientific community, structuring itself around the idea of scientific knowledge as a public asset that should, therefore, be accessible to all. Maybe we can now consider the Berlin declaration (2003-10-22: http://oa.mpg.de/openaccessberlin/berlindeclaration.html) as the first formalisation of the scientific construction paradigm change, since document was approved by representatives of European scientific institutions and started from the assumption that knowledge dissemination involves making it available at a large scale, in a chain of events involving a) support to Open Access publication for researchers and scholarship holders, b) encouragement of cultural heritage owners in order to make their resources available on the Internet, c) development of forms of evaluation for Open Access contributions in order to guarantee scientific quality and good practices, d) advocacy of the acknowledgement of Open Access publication and e) compensation of the authors of the articles, not in terms of royalties or copyrights, but prestige for publishing in journals influential in their field.

\section{OBS* as a Case Study}

Observatorio $\left(\mathrm{OBS}^{*}\right)$ is an international interdisciplinary e-journal that publishes peerreviewed articles. It presents empirical and theoretical research aiming at promoting a better understanding of communication phenomena. The journal extends its scope from issues related to media and the novel usages of the Internet, through the challenges surrounding the evolution of new media platforms, to the dynamics of service innovation in the telecommunications industry. It welcomes work from academics, practitioners and policymakers and is open to contributions coming from all branches of social science inquiry and the humanities. Its formula of Open Access ensures maximum of public availability of research work. Free access papers going through a sound scholarly process of peer-review present a mix of key advantages to authors and readers such as high scientific standards and worldwide ready dissemination.

The multilingual approach of (OBS*) is one of its distinctive characteristics. The e-journal accepts and publishes manuscripts submitted in English, Spanish, Italian, French, Portuguese, Catalan and Galician. 
What is intended here is, taking advantage of several statistic linked to (OBS*) growth, to verify until what point an online jounal like $\left(\mathrm{OBS}^{*}\right)$, centred in the fields of media and communication, largely surpasses the spectrum of publication consumption in similar areas, but in the traditional format (paper or book). This way, we can notice OBS* has been having an exponential growth in different aspects, not only the number of access to the online platform that gives access to all published texts, but also on the number of downloads and article consultation.

\section{Monthly History - year of 2007 (the beginning of OBS*)}

Source:http://www.obercom.pt/awstats/awstats.pl?month=04\&year=2007\&output=main\&co nfig=obs.obercom.pt\&framename=index

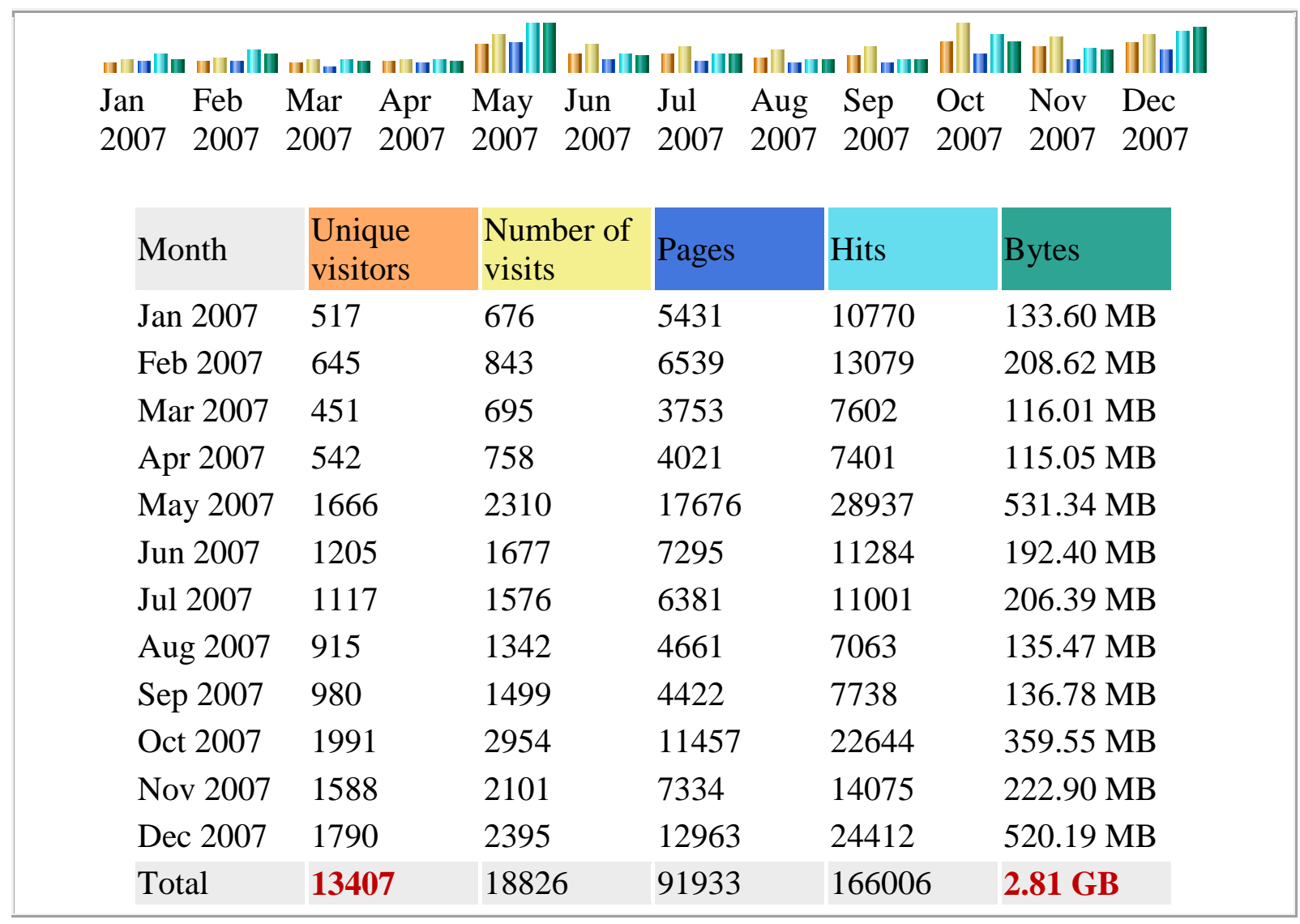

In 2007, first year of the magazine, the number of unique visitors was 13407 with the number of article downloads being equivalent to $2.81 \mathrm{~GB}$. 


\section{Geographical Reach - 2007}

Countries (Top 10) - Full list

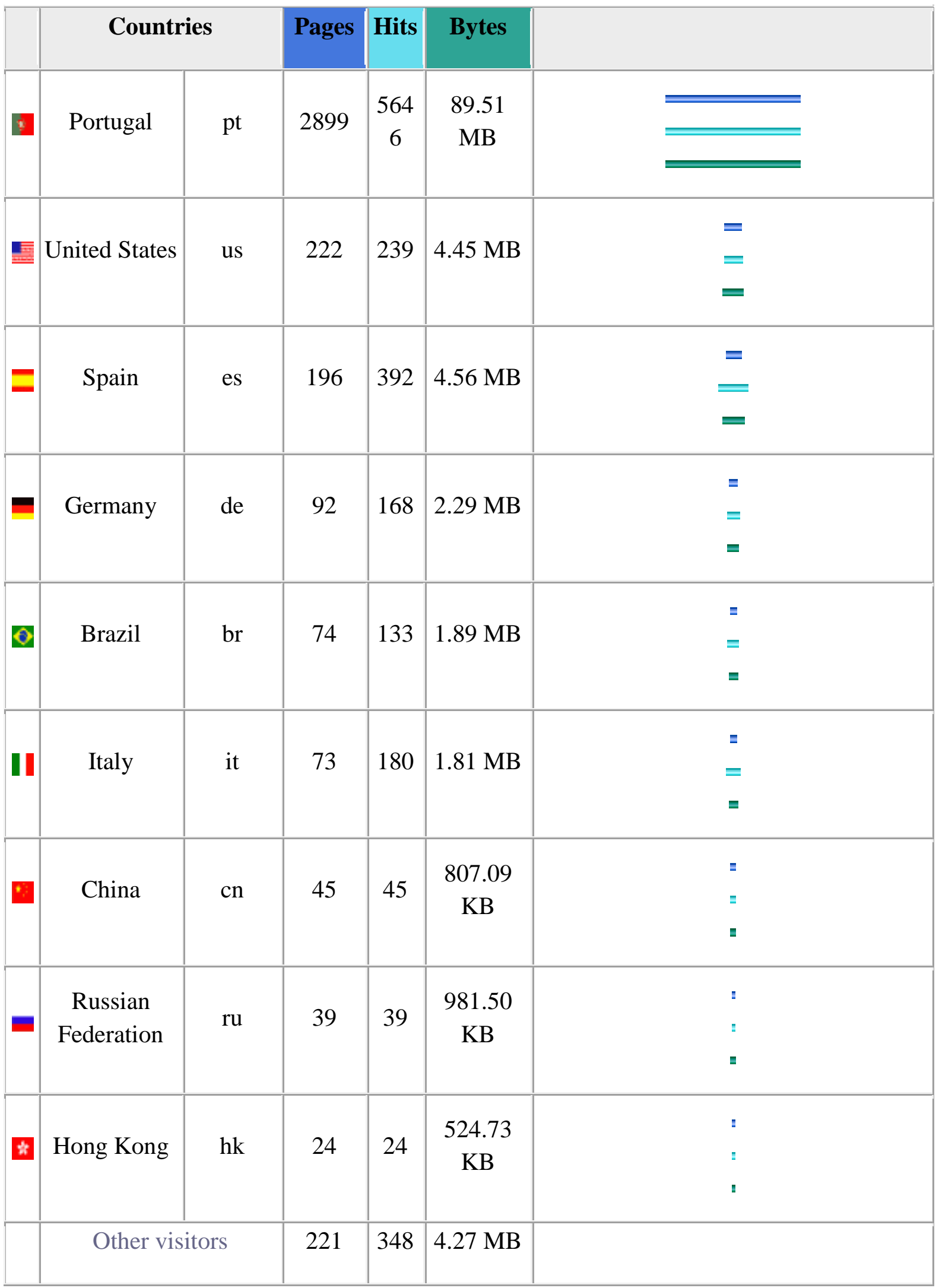


Concerning $\left(\mathrm{OBS}^{*}\right)$ geographical reach, we immediately notice that during the first year of the journal, article consumption became worldwide, with several countries in different continents being represented in the list of (OBS*) greatest users. Still, and evaluating the volume of global use, Portugal was clearly the most represented country, with countries such as China or Russia and Hong Kong Canton showing small significance.

\section{8}

Monthly History

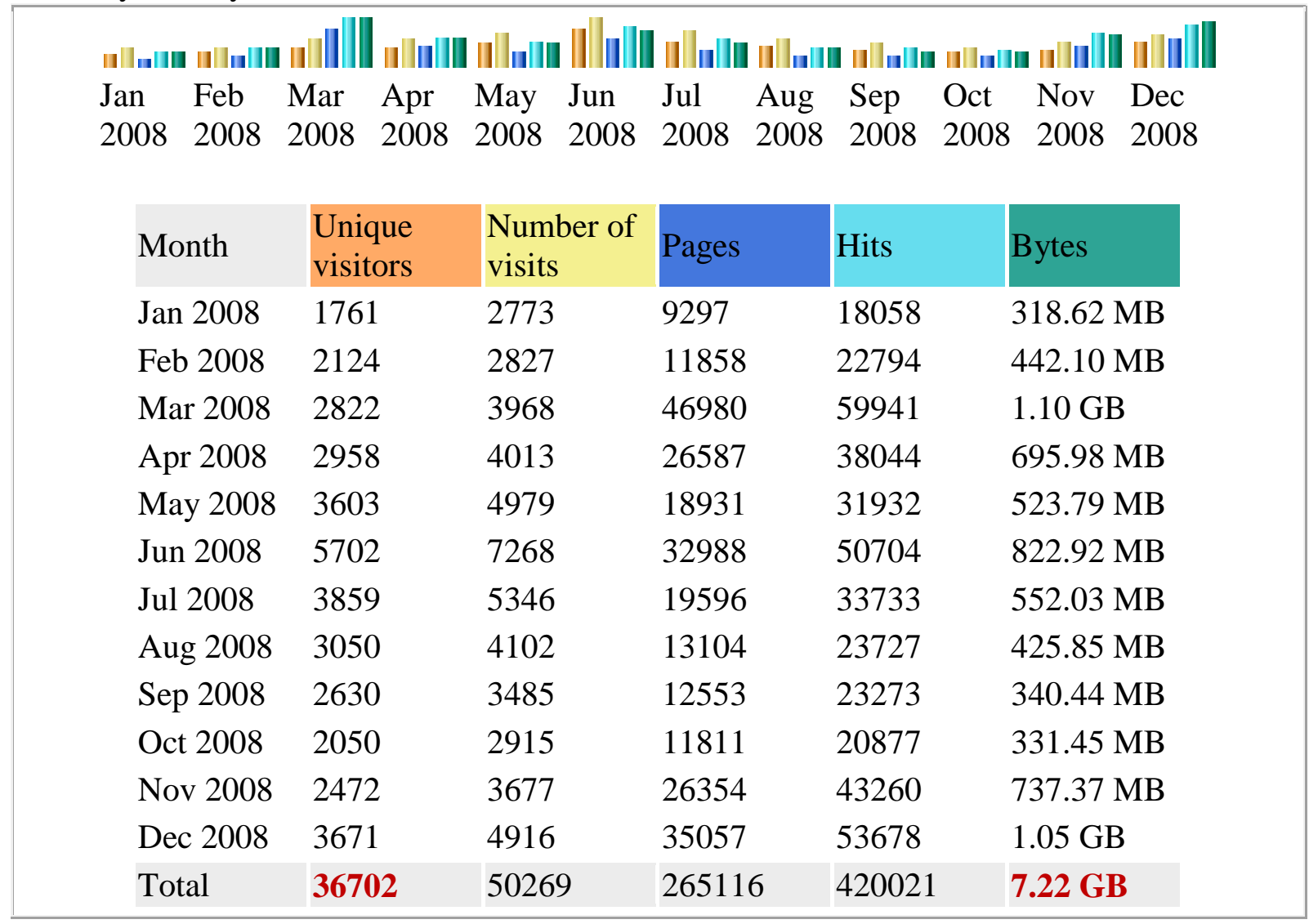

In 2008, the number of (OBS*) use, when compared with the previous homologous period, already had around $274 \%$ growth. Its growth surpassed $256 \%$, concerning the volume of downloads (measured in GB). 


\section{Geographical Reach - 2008}

Countries (Top 10) - Full list

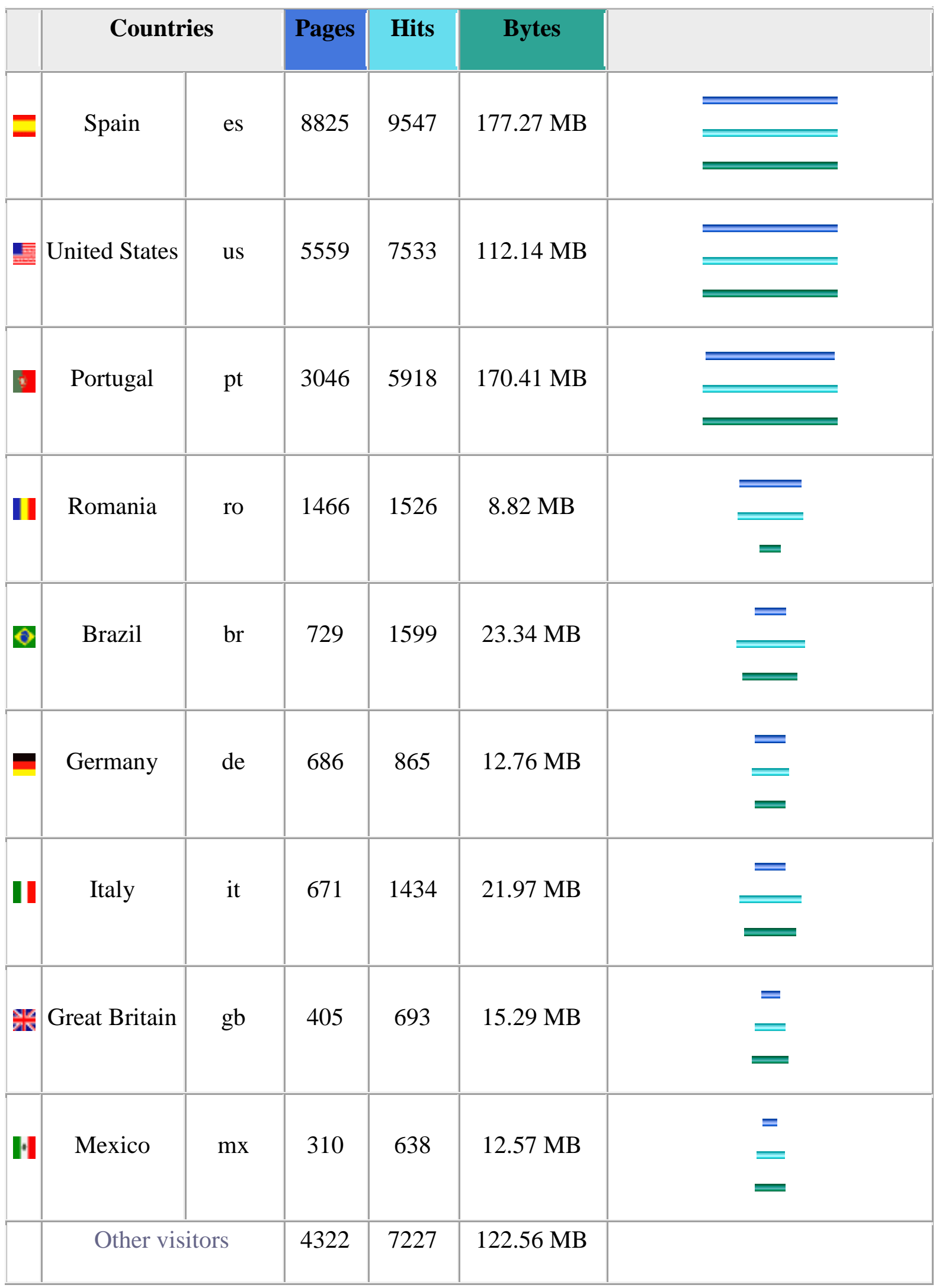


Concerning use, by country, Spain eventually surpassed Portugal in all use areas, with an USA approach being also apparent. Thus, within a year, (OBS*) reach not only recorded other territories on the political map, but it also documented larger consultation volumes, in other areas other than Portugal, its country of origin.

\section{9}

Monthly History

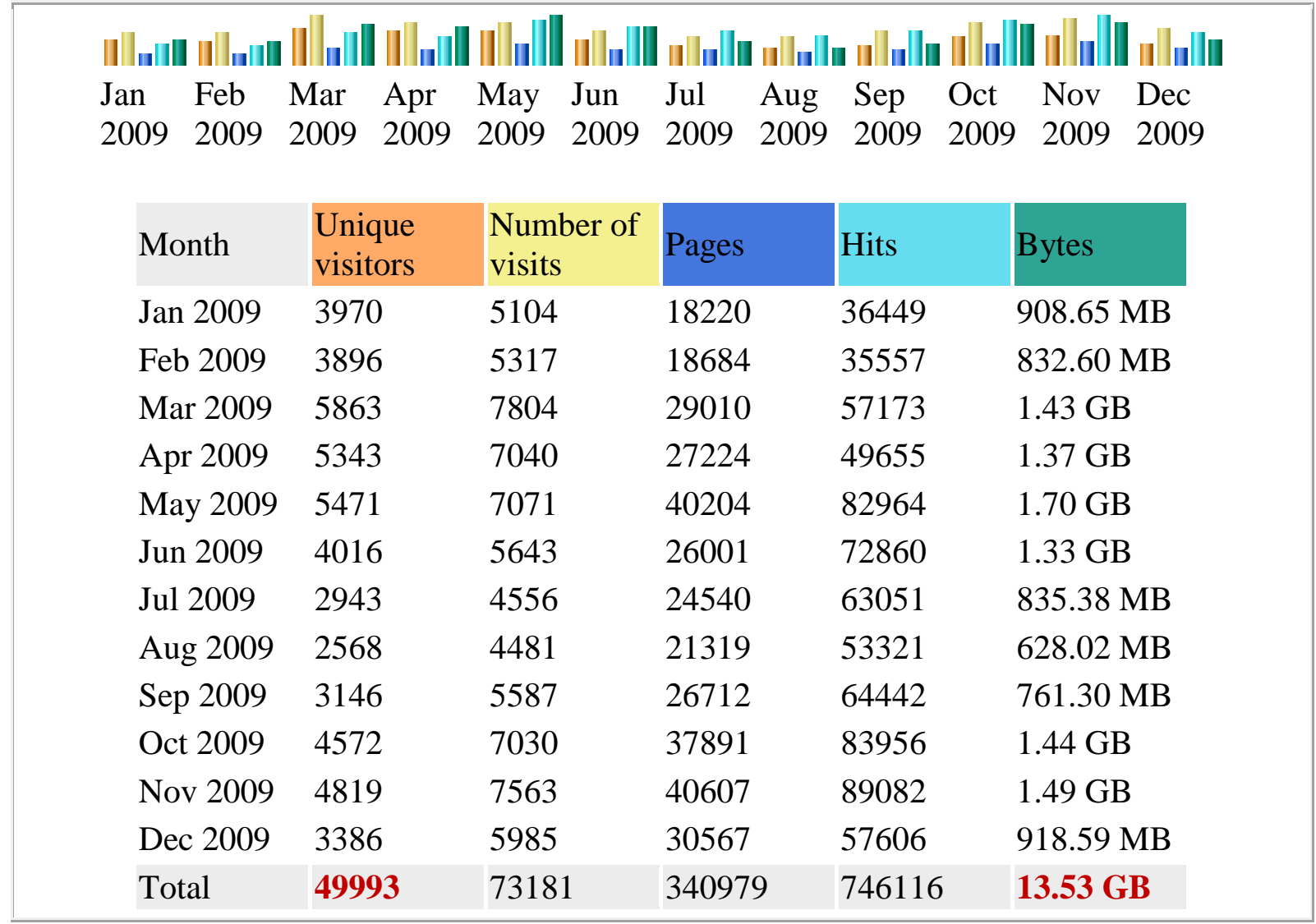

During its third year of existence, (OBS*) had around 373\% growth in the number of unique visitors, when compared to the first year of 2007 , and $136 \%$ when compared with the previous year, 2008. Concerning the volume of article use, measured in GB, its growth was 481\% when compared with 2007 and $187 \%$ when compared with 2008. 


\section{Geographical Reach - 2009}

Countries (Top 10) - Full list

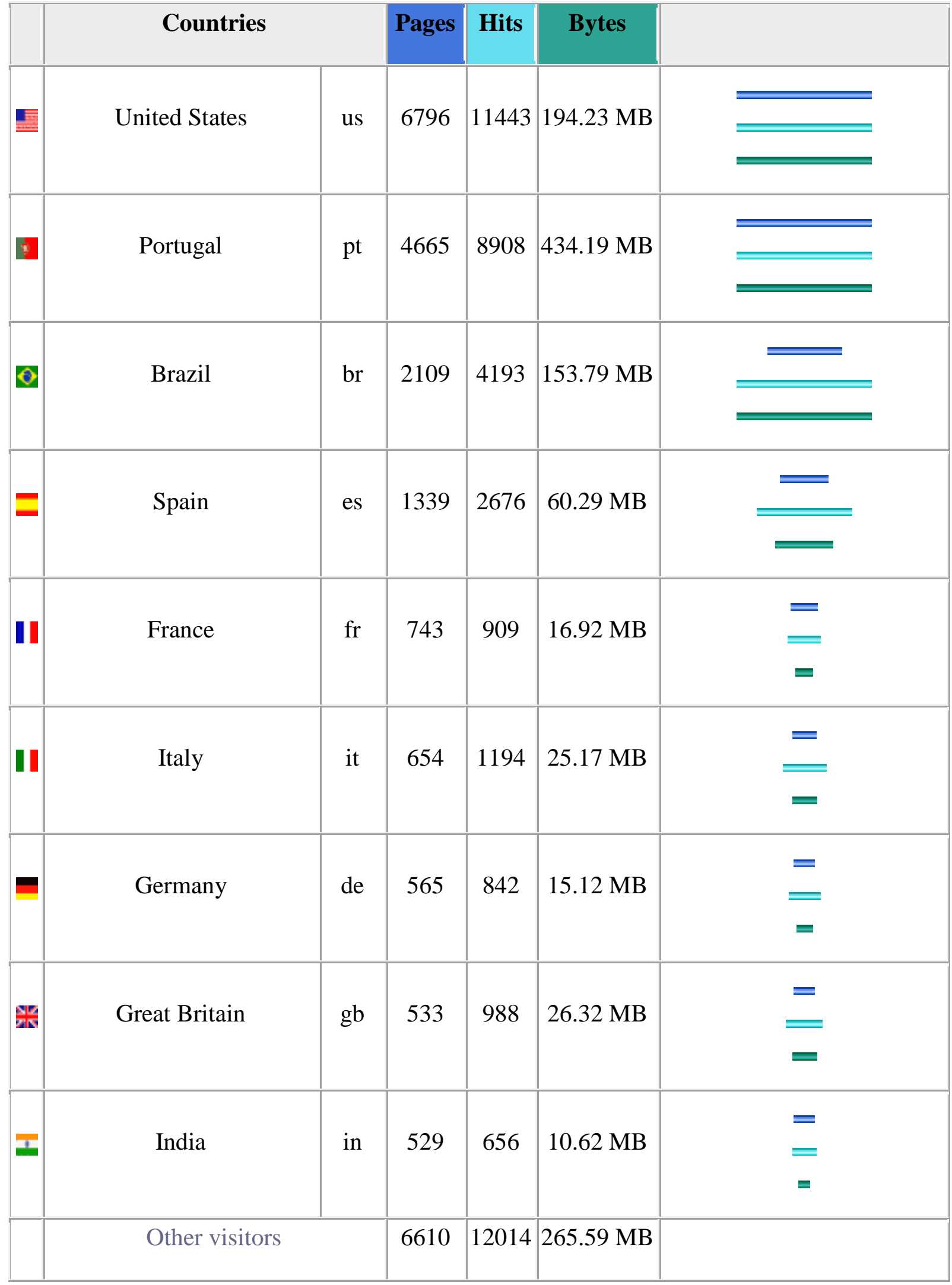


Concerning (OBS*) geographical reach for 2009, the main change is in the fact that the United States and Portugal became the main users of (OBS*) products, Spain decreasing and Brazil growing around $660 \%$ in consumption made in the (OBS*) Observatorio platform.

Having now published its twelfth open access issue and a total of 195 papers (count made at the end of 2009), (OBS*) achieved more than 196000 downloads up to the month of February 2010.

If we consider only the most seen article in each issue, we notice that, for example, the article of Piet Bakker and Saara Taalas (http://www.obercom.pt/ojs/index.php/obs/article/view/61), published in the inaugural issue of (OBS*), has already more than 2000 visits. Another article, from Soloanga and Muriel, “Women stereotypes portrayed in print ads by luxury fashion brands" (http://www.obercom.pt/ojs/index.php/obs/article/view/104), published in the first issue of 2008 , the second year of $\left(\mathrm{OBS}^{*}\right)$, has today a total number of downloads nearing 1300. This leads us to the supposition that the reach of a single article per journal largely overcomes the usually constant number of scientific magazine issue and namely those that, in Portugal, belong to the fields of Social Sciences and Communication. Let's see the following examples:

\begin{tabular}{|ccc|}
\hline $\begin{array}{c}\text { Circulation of scientific magazines in traditional } \\
\text { format }\end{array}$ & Numbers/Prints & Other considerations \\
Sociology Problems and Practices & 600 & \\
Social Analysis & 800 & Already online \\
Communication and Languages Magazine & 600 & Publisher went \\
Communication and Society & Closed & \\
Kaleidoscope Communication and Culture & & \\
Magazine & 500 &
\end{tabular}

As we can see, publications that remain faithful to the traditional paper format in their fields have a considerable smaller reach than $\left(\mathrm{OBS}^{*}\right)$. The difference is so clear that it is almost accessory to point out two other conditions that contribute to a maximisation of this 
differentiation. On the one hand, while in the traditional format of the magazines mentioned in the previous table, print has a pre-defined number, on the online formats such as (OBS*), article access is endless, continuous in time and it's growth is explained and fed on the duration time of the publication. Unless the article is, for some reason, taken from the access platform, its consumption is not rigid or dependent of other factors, such as the number of paper copies available for consultation, the publication budget, the geographical limitation and circulation reach, et cetera. On the other hand, the greater reach of the journal in geographical terms, (sine qua non condition of the great potential offered by information technologies) turns growth of international articles into a given fact in the journal (greater geographical reach, greater tendency to receive more articles, from more parts of the world), as it also increases the network effect necessary to the survival and vitality of the journal. Since its first issue, OBS* published the work of 288 authors and co-authors from 30 countries: Portugal, Spain, The Netherlands, Finland, United States, Belgium, Switzerland, Germany, Poland, Ukraine, Turkey, Brazil, Chile, Hungary, Canada, United Kingdom, Slovenia, Australia, Denmark, Romania, Cyprus, Greece, Czech Republic, Denmark, Norway, Sweden, Puerto Rico, Singapore, China and Italy. Thus, as a testimony of its global identity and multilingual nature, OBS* published papers in English, Spanish, Italian, Galician, French, Brazilian and European Portuguese and the first twelve issues were read in 159 countries.

Ultimately, (OBS*) approach has a special importance in the sense it appears as a consistent and practical explanation of the theoretical assumptions Knowledge Society is based upon, highlighting at the same time the relevance and contribution of Open Science towards the prosecution of this paradigm change, which goes from the self-centred, closed and small reach knowledge Society, to a more accessible knowledge Society, which content democratization is explained by the greater range it has under the accessibility point of view.

On the other hand, there are two other aspects that appear to regulate the success of a scientific journal and its credibility in Academia.

To begin with, we must mention the editorial board as the first impact in approaching the journal. It is quite relevant the first impression that the author establishes with the journal in a 
way that the more he feels identified with some of these names on the editorial board, the more positive will be the first contact with the journal itself.

That is, it seems quite evident to assume the idea that when we first access the website of a journal and, associated with it, we see some of the leading experts in a given area, the first impression of that journal tends to be positive and will come out strengthened somehow. Regarding to our (OBS*) e-journal, an online publication in the field of Media and Communication, we can find already some associate editors of renown.

The other key aspect when it comes to the recognition of a journal is related to the systems to which a publication appears associated/indexed. Basically, this aspect is important from the moment we want to make information globally accessible. Ultimately, these systems, or databases, allow us to access content from a datacentre and bibliometric perspective, using key-words or concepts that are intended to be discussed in scientific articles. And the (OBS *) journal has also done some work here, already appearing associated with EBSCO Publishing or SciELO, and being currently in the middle of an evaluation process that takes place in ISI Web of Knowledge and SCOPUS Elsevier.

\section{Pros versus Cons: the comparison.}

This new science distribution and production paradigm has, in our opinion, much more pros than cons. Some advantages are necessarily linked with turning science research reusable; research material accessible with one click (increasing not only content dissemination, but also consultation feasibility); integrating content produced in open repositories, resorting to common database construction protocols able to integrate metadata with information concerning a given article and allowing its generalised access; making effort combination more viable, not only in the sense of regulating scientific production repetition, but also in the sense of broadening contributions to several specialists in different parts of the globe, in a form of non-presential scientific partnership. As Klump (2006: p.1) states, "This lack of access to scientific data is an obstacle to interdisciplinary and international research. It causes unnecessary duplication of research efforts, and the verification of results becomes difficult, if not impossible.".

On the one hand, this paradigm change minimised the fast disappearance of the traditional scientific distribution vehicle in paper format, heavily contributing for content reaching more 
people, and growing, in number of users, in a way that is continuous and non-dependant of financing or other party's idiosyncrasies, such as designers, publishers, etc. "The average price of a science journal has risen four times faster than inflation for the past two decades. The result is an access crisis in which no institutions can afford access to the full range of journals." "The price of journals increased considerably in the last two decades, generating an access crisis and forcing institutions to cancel subscriptions" (Canessa, Zennaro, 2008: p.14). In the same sense, Cardoso (et al: 2009) states the rise in subscription prices generated concern and revolt regarding commercial publication in the academic world. There are even examples of already perfectly established publications in the scientific domain, that have decided to add to the paper publication the possibility of those same content being available on the Internet, perhaps with the intention of beginning to move in safer ground or choosing a progressive transition towards the digital format alone (see table Circulation of scientific journals in traditional format). The journal Análise Social (Social Analysis) is a clear example of that. In this sense, Terry (2005: http://www.plosbiology.org/article/info:doi/10.1371/journal.pbio.0030097) mentions that "Open Access debate is not, in its essence, a debate about economy, but about access". This ultimately means, although the economical aspect is not the main focus of this issue, that we cannot ignore the fact that this transition from a more traditionalist and commercial way of scientific distribution towards a more open and democratised content distribution, results, on itself, in a process freedom that would not be possible in any other way. This, linked to the greater range of science produced, generates an unprecedented public good, with an electronic distribution at a global scale of academic journals with peer revision and free access by all scientists, scholars, professors, students and other curious minds.

On the other hand, the main limitations of a platform such as (OBS*), which supports scientific knowledge production and distribution in the models we have already defined, ends up by finding some conflict points in this triad relationship, this is between the author, the journal and its act of moderating, and the reviewers. What is the reason for this conflict? If we want to be clear, any signs of disagreement between the three parties will always have its origins in individual wills. If on one side, it is quite possible that reviewers suggest alterations to the original model submitted by the author, on another side it is also possible that the author does not acknowledge such suggestions made by the reviewers. 
I chose not doing the revision for two reasons: the first being that I believe since the text was rewritten for revision; reviewers should also have redone their opinions. After all, the majority of questions pointed out were reviewed and the indication "reread opinions", as I see it, does not show that a new reading of the text sent was made. The second is that the main argument of opinion maker 01 about the text was the small knowledge in Europe of the theoretical guideline I used. In fact, one of the purposes of this research is the diffusion of the knowledge acquired. And I believe it is healthy in Academia that we do not close our eyes to research made outside the place we are. If questioning were about concept construction, I would understand and would try to correct it. Even so, in the text, I recovered the base in other authors (many of them European) that the perspective of hypermedia radio brings. And the observation about the theoretical perspective outside Europe was kept. (Anonymous 1)

I am sad, I cannot understand how the article was fine before the reformulation and now it is wrong. I will review it again. (Anonymous 2)

Still, this being the most common conflict pattern, differences do not end here. There have been other cases, where articles, already with a positive opinion and in the final editing and publication process, raise unexpected and extremely critical comments from the reviewers, which, unsatisfied, regret the fact their revision was neglected.

I did a Compare in word, and noticed what was changed, some English mistakes and two phrases. This has nothing to do with following my comments; it simply disrespects the Review process. Submitting this, saying that it was changed is bad faith. (Anonymous 3)

In parallel, there is also the danger of elongating too much the reviewing process of articles that are presented to us. Therefore, if the previous problem was related with the lack of convergence of opinions between the parties involved in the process, here the problem lies in a certain absence of commentary or attention from the person proposed to review. This means that, as reviewers are proposed, if we do not receive an answer from them, the authors end up 
reminding us they have a submitted article without reply, which may discredit the journal with this potential author and collaborator of the publication.

Dear editors, more than a year has passed now since we submitted our paper we have not received any reviews yet. Just now I found a mail in your review system asking for incorporating changes for the April edition. We never got that notification e-mail nor any reviews. (Anonymous 4)

Therefore, more than a monitoring and organisation role, the role of the editing team of a scientific journal with an online publication must be an appeasing one, in the sense of managing conflicts and attempting to promote and converge the author's and reviewers wills. Ultimately, unlike traditional publications, where the choice of written articles follows an unilateral publication logic, where the editorial will and decision process are sovereign, in online journals and publications (to which (OBS*) belongs), the final decision goes through three parts, and balance is not so easy to achieve.

Beyond all this, as mentioned above, this kind of journals depend largely on the first impact that the authors establish with the journal and, as we have already stated, the two most important aspects for an initial impact are: a <strong> board of associate editors, renowned and with recognized merit as well as the association of the journal to some indexing systems (such as ISI) that facilitate the global access to articles published in each issue. And this is not always easy, since these processes are slow and depend on the agreement of many individual wills to be succeed. And, moreover, "the use of indexing systems may ensure quality, but it discriminates against smaller journals and new journals trying to get a foothold" (Leibman, founding editor of IJEM, in World Association of Medical Editors: http://www.wame.org/wame-listserve-discussions/the-role-of-indexing-systems).

However, we could say that these cons of the existence of an online scientific publication are, at the most, small obstacles when compared with the great advantages linked to it, whether at the author level, with a greater dispersion of articles signed in exclusivity, whether at the consumption level, since it blurs that restraining dualism between those that have no way of consuming science and those that have and therefore use it. 
Deep down, the expression Scientific Philanthropy is the best to define such process, since all parts of a system seem to benefit, including the whole, that establishes itself with a real approach to what we previously defined as Knowledge and Information Societies or the pillar of growing societies. 


\section{References}

Armbruster, C. (2008), - Cyberscience and the Knowledge-Based Economy, Open Access and Trade Publishing: From Contradiction to Compatibility with Nonexclusive Copyright Licensing\|, in International Journal of Communications Law and Policy, No. 12, 2008; Policy Futures in Education, Vol. 6, No. 4, 2008. Available at SSRN: http://ssrn.com/abstract=938119.

Atkins, D. E., [et al.] (2003), Revolutionizing Science and Engineering Through Cyberinfrastructure. Available at: http://www.nsf.gov/od/oci/reports/atkins.pdf.

Baker, M., Buyya, R., \& Laforenza, D. (2002), Grids and Grid technologies for widearea distributed computing\|, in Software: Practice and Experience, 32(15), 1437-1466.

Becker, Peter and Clark, William (2001), Little Tools of Knowledge, The University of Michigan Press, USA.

Benkler, Y. (2002). Coase's Penguin, or, Linux and The Nature of the Firm. Available at: http://www.benkler.org/CoasesPenguin.html

Berlin Declaration on Open Access to Knowledge in the Sciences and Humanities.

Available at: http://oa.mpg.de/openaccess-berlin/berlindeclaration.html

Bowker, G. C. (2001), - The New Knowledge Economy and Science and Technology Policyll, in Encyclopedia of Life Support Systems (EOLSS), Paris, UNESCO.

Canessa, E., Zennaro, M. [eds.] (2008), Science Dissemination using Open Access: A compendium of selected literature on Open Access, ICTP - The Abdus Salam International Centre for Theoretical Physics. Available at: http://sdu.ictp.it/openaccess/SciDissOpenAccess.pdf

Cardoso, G., Caraça, J., Espanha, R., Triães, J., Mendonça, S. (2009), —As Políticas de Open Access. Res publica científica ou autogestão?\| in Sociologia, Problemas e Práticas, Oeiras, Celta Editora.

Castells, M. (2002). A Era da Informação: economia, sociedade e cultura, Vol.1: A Sociedade em Rede, Lisboa, Fundação Calouste Gulbenkian.

Conley, J. P., \& Wooders, M. (2009), —But what have you done for me lately? Commercial Publishing, Scholarly Communication, and Open-Access $\|$ in Economic Analysis, 39(1), 71-88.

David, P. A. (2003), - The Economic Logic of -Open Sciencell and the Balance between Private Rights and the Public Domain in Scientific Data and Information: A Primer\| 
in The Role of the Public Domain in Scientific and Technical Data and Information, Washington, DC; National Academies Press. Available at: http://ideas.repec.org/p/wpa/wuwpdc/0502006.html

Downes, S. (2007), -Models for Sustainable Open Educational Resources\| in Learning, 3.

Eco, U. (1993), Apocalípticos e Integrados, São Paulo, Perspectiva.

Gass, A. (2005), - Paying to Free Science: Costs of Publication as Costs of Research\| in Serials Review, 31(2), 103-106.

Hajjem, C. [et al.] (2005.), -Ten-Year Cross-Disciplinary Comparison of the Growth of Open Access and How it Increases Research Citation Impactl in Bulletin of the IEEE Computer Society Technical Committee on Data Engineering.

Harnard, S., Brody, T. (2004), -Comparing the Impact of Open Access (OA) vs. Non- OA Articles in the Same Journals\| in D-Lib Magazine, 10:6. Available at: http://www.dlib.org/dlib/june04/harnad/06harnad.html.

Harnad, S. [et al.] (2008), - The Access/Impact Problem and the Green and Gold Roads to Open Access: An Update\# in Serials Review, 34, 36-40.

Himanen, P., Torvalds, L., Castells, M. (2001), The Hacker Ethic and the Spirit of the Information Age, London, Vintage.

Jankowski, N. W. (2007), -Exploring e-science: An introduction\| in Journal of ComputerMediated Communication, 12(2), article 10.

Available at: http://jcmc.indiana.edu/vol12/issue2/jankowski.html.

Klump, J. [et al.] (2006), Data publication in the open access initiativell in Data Science Journal, 5(June), 79-83.

Lakhani, K. R., [et al.] (2007), -The Value of Openness in Scientific Problem Solving\|, in Biotech Business.

Maurer, S. M. (2003), -New Institutions for Doing Science: From Databases to Open Source Biologyll, in. Journal of Science and Technology.

Moore, K. (2008), Disrupting Science: Social Movements, American Scientists, and the Politics of the Military, 1945-1975, New Jersey, Princeton University Press.

Nentwich, M. (2005), -Cyberscience: Modelling ICT-induced changes of the scholarly communication system\|, in Information, Communication \& Society, 8:4, $542-560$.

OCDE (2004) Science, technology and innovation for the 21st century. Meeting of the OECD Committee for Scientific and Technological Policy at Ministerial Level, 29-30 January 2004 - Final Communique. 
Availableat:http://www.oecd.org/document/0,2340,en_2649_34487_25998799_1_1_1_1,00.h $\underline{\text { tml. }}$

Pidgeon, N. (2008), Risk, Uncertainty and Social Controversy: From Risk Perception and Communication to Public Engagement, in Bammer, G., Smithson, M. (2008), Uncertainty And Risk: Multidisciplinary Perspectives, Towbridge, Cromwell Press.

PROBST, Gilbert; RAUB, Steffen; ROMHARDT, Kai. Gestão do Conhecimento: os elementos construtivos do sucesso. (Tradução Maria Adelaide Carpigiani) Porto Alegre. Bookman. 2002

Raymond, E. S. (1997), Release Early, Release Often. Disponível em HTTP: http://www.catb.org/ esr/writings/cathedral-bazaar/cathedral-bazaar/ar01s04.html.

Rodrigues, Maria João et al (2009), Europe, Globalization and The Lisbon Agenda, Edward Elgar, MA, USA.

Swan, A., Brown, S.N. (2004a), JISC/OSI Journal Authors Survey Report. Disponível em HTTP: http://www.jisc.ac.uk/uploaded_documents/JISCOAreport1.pdf.

Swan, A., Brown, S.N. (2004b), -Authors and Open Access Publishing\|, in Learned Publishing 17 (3): 219-224. Disponível em HTTP: http://cogprints.org/4123/1/Authors_and_open_access_publishing.pdf.

Terry, R. (2005) Funding the way to open access. PLoS Biol 3(3): e97.40. Available at: http://www.plosbiology.org/article/info:doi/10.1371/journal.pbio.0030097

Vadén, T. (2006), —'Intelectual Property' and Knowledge Creation in Disorganizationsl, in E-Learning, 3:3.

Watson, R., Crawford, M. and Farley, S. (2003), Strategic Approaches to Science and Technology in Development. World Bank Policy Research Working Paper No. 3026. Available at SSRN: http://ssrn.com/abstract=636388.

Willbanks, J., Reynolds, W. N. (2006), Introduction to Science Commons. Available at: http://sciencecommons.org/wpcontent/uploads/ScienceCommons_Concept_Paper.pdf .World Association of Medical Editors: http://www.wame.org/wame-listservediscussions/the-role-of-indexing-systems .

Zakai, A. (2007), - The Rise of Modern Science and the Decline of Theology as the =Queen of Sciences` in the Early Modern Erall, in Reformation \& Renaissance Review, 9:2.41. 